\title{
TUGAS PEMERINTAH DALAM MENYELESAIKAN MASALAH - MASALAH SOSIAL: TINJAUAN MENGENAI MASALAH BADAN USAHA MILIK DESA
}

\author{
Eka Nurcahya \\ Fakultas Ilmu Sosial dan Ilmu Politik \\ Universitas Padjadjaran \\ kanurcahya@gmail.com
}

\begin{abstract}
ABSTRAK
Penelitian ini bertujuan untuk mendeskripsikan tentang tugas pemerintah dalam menyelesaikan masalah-masalah sosial tinjauan mengenai masalah BUMDes. meningkatkan kesejahteraan ekonomi warga desa melalui pengembangan usaha ekonomi. Disamping itu, keberadaan BUMDes juga membawa dapak terhadap peningkatan sumber pendapatan asli desa (PAD) yang memungkinkan desa untuk mampu melakukan sebuah pembangunan dan juga untuk peningkatan kesejahteraan secara lebih optimal. Metode penulisan jurnal ini melalui studi literatur melalui berbagai informasi dalam dokumen, buku, jurnalilmiah, koran, majalah, serta sumber informasi dari laman situs/website melalui internet. Hasil penelitian ini menunjukkan bahwa membangun Indonesia dari pinggiran dengan memperkuat daerah dan desa merupakan agenda prioritas Indonesia. Tujuannya untuk memajukan perekonomian masyarakat desa dan mengatasi kesenjangan pembangunan nasional. Hal ini dapat diwujudkan melalui pembentukan Badan Usaha Milik Desa. Ditinjau dari karakteristik masalah publik menurut Dunn, BUMDes ini termasuk dalam masalah publik. Analisis dari karakteristik saling bergantung (interdependence) dan akibat penilaian subjektivitas pemerintah untuk turut andil mengatasi masalah sosial terkhusus faktor ekonomi yang dirasakan oleh masyarakat. Sehingga pemerintah mengeluarkan kebijakan sebagaimana diatur pada Bab X Undang-undang Nomor 6 Tahun 2014 dan Permendes PDTT Nomor 4 tahun 2015.
\end{abstract}

Kata Kunci: Kebijakan, Pembangunan Nasional, BUMDes

\begin{abstract}
This research aims to describe the government's task in resolving social issues of the review regarding BUMDes problem. Increase the economic welfare of villagers through the development of economic efforts. In addition, the existence of BUMDes also brings to the improvement of the original source of income of the village (PAD) that allows the village to be able to do a development and also to improve the welfare more optimally. This method of journal writing through literature study through various information in documents, books, journalism, newspapers, magazines, as well as the source of information from the site/website through the Internet. The results of this research show that building Indonesia from the periphery by strengthening the region and village is Indonesia's priority agenda. The goal is to advance the village community economy and overcome the national development gap. It can be realized through the formation of village owned enterprises. Reviewed from the characteristics of a public problem according to Dunn, this BUMDes is included in public issues. Analysis of characteristics of interdependence (interdependence) and due to the judgment of the subjectivity of the Government to participate in addressing the social problems of the specific economic factors perceived by the community. So the government issued a policy as stipulated in chapter X Undang-Undang No 6 Tahun 2014 and Permendes PDTT Nomor 4 Tahun 2015.
\end{abstract}

Keywords: Policy, Development, BUMDes

\section{Pendahuluan}

Negara Indonesia sebagai negara yang berdasar atas hukum memiliki beberapa tujuan penyelenggaraan negara, sebagaimana diamanatkan dalam Pembukaan Undang-Undang Dasar Negara Republik Indonesia Tahun 1945. Tujuan negara Indonesia antara lain adalah 


\section{Tugas Pemerintah Dalam Menyelesaikan \\ Masalah - Masalah Sosial: Tinjauan Mengenai Masalah Badan Usaha Milik Desa \\ (Eka Nurcahya)}

untuk melindungi segenap bangsa dan seluruh tumpah darah Indonesia, memajukan kesejahteraan umum, mencerdaskan kehidupan bangsa, dan ikut melaksanakan ketertiban dunia yang berdasarkan kemerdekaan, perdamaian abadi, dan keadilan sosial.

Realita yang terjadi saat ini banyak sekali masalah sosial di masyarakat. Masalah sosial adalah keadaan yang dianggap oleh anggota masyarakat yang berpengaruh sebagai sesuatu yang tidak diinginkan, tidak dapat ditoleransi, atau sebagai ancaman terhadap nilai-nilai dasar masyarakat, dan memerlukan tindakan kelompok untuk menyelesaikannya. Masalah sosial berbeda dengan masalah-masalah yang lain karena hubungannya yang erat dengan institusi dan norma. Masalah sosial dinggap masalah karena melibatkan hubungan manusia serta nilai-nilai dan menjadi gangguan kepada harapan masyarakat atau hal-hal yang dianggap perlu dari segi moral.

Pemerintah secara arti luas sebagai lembaga eksekutif, legislatif, dan yudikatif memiliki peranan strategis untuk mengatasi masalah-masalah sosial yang ada di masyarakat. Salah satu misi pemerintah pada saat ini yaitu untuk membangun daerah pedesaan yang dapat dicapai melalui sebuah pemberdayaan masyarakat dengan tujuan untuk meningkatkan produktivitas dan keanekaragaman usaha yanga ada, terpenuhinya sarana dan fasilitas untuk mendukung peningkatan ekonomi desa, membangun dan memperkuat institusi yang mendukung rantai produksi dan pemasaran, serta mengoptimalkan sumber daya manusia sebagai dasar pertumbuhan ekonomi desa. Badan Usaha Milik Desa (BUMDes) merupakan instrument pemberdayaan ekonomi lokal dengan berbagai ragam jenis usaha sesuai dengan potensi yang dimiliki desanya. Pengembangan potensi ini memiliki tujuan untuk meningkatkan kesejahteraan ekonomi warga desa melalui pengembangan usaha ekonomi. Disamping itu, keberadaan BUMDes juga membawa dapak terhadap peningkatan sumber pendapatan asli desa (PAD) yang memungkinkan desa untuk mampu melakukan sebuah pembangunan dan juga untuk peningkatan kesejahteraan secara lebih optimal.

BUMDes sejatinya sebagai lembaga sosial yang berpihak kepada kepentingan masyarakat melalui kontribusinya sebagai penyedia pelayanan sosial. Namun BUMDes juga sebagai lembaga komersial dimana BUMDes bertujuan untuk mencari keuntungan melalui penjualan barang atau jasa yang diperuntukan kepada masyarakat. BUMDes sebagai badan hukum, dibentuk berdasarkan tata perundang-undangan yang berlaku, dan sesuai dengan aturan yang berlaku di desa.
Dalam Undang-Undang Nomor 32 Tahun 2004 tentang Pemerintah Daerah pada Pasal 213 ayat 1-3 disebutkan bahwa desa dapat mendirikan Badan Usaha Milik Desa (BUMDes) sesuai dengan kebutuhan dan potensi desa. Sesuai dengan aturan tersebut, pembentukan BUMDes didasarkan atas kebutuhan dan potensi yang dimiliki desa, dengan tujuan sebagai upaya peningkatan kesejahteraan masyarakat.

Dalam hal ini perencanaan dan pembentukannya, BUMDes dibangun atas inisisai masyarakat desa, serta mendasarkan pada prinsipprinsip kooperatif, partisipatif, dan emansipatif. Hal yang paling penting adalah bahwa pengelolaan BUMDes harus dilakukan secara profesional, kooperatif, dan mandiri. Dengan demikian, bangun BUMDes dapat beragam di setiap desa di Indonesia. Sehubung dengan itu, maka untuk membangun BUMDes diperlukan informasi yang akurat dan tepat tentang karakteristik kelokalan termasuk ciri sosial budaya masyarakat. Melihat posisi BUMDes dalam menghadapi realitas desakan arus intervensi modal domestik dan asing yang kini menjadikan desa sebagai sasaran pengembangan usaha sangat keras sekali, disamping itu BUMDes ini hanya bermodal tak seberapa jika dibandingkan dengan swasta yang selalu bermodal besar. Dengan sumber daya alam yang dimiliki desa, hal ini sangat rawan sekali terjadi intervensi modal dan pasar di pedesaan. Kehadiran BUMDes sendiri akan menjadi penangkal bagi kekuatan korporasi asing dan nasional. Diharapkan BUMDes ini mampu menggerakan dinamika ekonomi desa, dan sebagai perusahaan milik desa.

\section{Tinjauan Pustaka}

\section{Masalah Sosial}

Masalah kebijakan publik adalah nilai, kebutuhan atau kesempatan yang belum terpenuhi, tetapi dapat diidentifikasi dan dicapai melalui tindakan publik. Informasi mengenai sifat masalah dan potensi pemecahannya dihasilkan melalui penerapan prosedur analisa kebijaksanaan perumusan masalah (Dunn, 1992:92).

James E.Anderson dengan mengutip pendapat David G.Smith memberikan pernyataan sebagai berikut:

"For policy purposes, a problem can be formally defined as condition or situation that produces needs or dissatisfactions on the part of people for which relief or redress is sought. This may be done by those directly affected or by others acting on their behalf' (untuk kepentingan kebijaksanaan, suatu masalah dapat diartikan secara formal sebagai kondisi 
atau situasi yang menghasilkan kebutuhankebutuhan atau ketidakpuasan-ketidakpuasan pada rakyat untuk mana perlu dicari cara-cara penanggulangannya. Hal ini dilakukan oleh mereka yang secara langsungterkena akibat oleh masalah itu atau orang lain yang punya tanggung jawab untuk itu).

Jones mengartikan “peristiwa” sebagai kegiatan-kegiatan manusia atau alam yang dipandang memiliki konsekuensi pada kehidupan sosial. Dan mengartikan "masalah" sama dengan pendapat Smith diatas yaitu: kebutuhan-kebutuhan manusia yang harus diatasi/dipecahkan (Islamy, 2004:79).

Masalah dapat dirumuskan sebagai ketidaksesuaian antara suatu ukuran (asas, norma, atau tujuan) dengan gambaran suatu keadaan sedang berlangsung atau diperkirakan akan terjadi. Dengan demikian, maka masalah adalah perbandingan ukuran yang dipakai dengan gambaran keadaan yang sedang berlangsung. Misalnya penyerobotan rumah dapat dipandang oleh pemerintah sebagai suatu masalah gangguan ketertiban umum atau sebagai masalah kekurangan perumahan atau dua-duanya, tergantung dari ukuran atau segi pandangan yang dipakai oleh pemerintah dan keadaan yang sedang berlangsung (Suryaningrat, 1989:12).

Perumusan masalah merupakan langkah awal dalam pembuatan suatu kebijakan publik. Menurut
William N. Dunn suatu perumusan masalah dapat memasok pengetahuan yang relevandengan kebijakan yang mempersoalkan asumsi-asumsi yang mendasari definisi masalah danmemasuki proses pembuatan kebijakan melalui penyusunan agenda (agenda setting ) (Dunn,2003: 26). Hal tersebut menyimpulkan bahwa kebijakan publik dibuat dikarenakan adanya masalah publik yang terjadi, sehingga permasalahan tersebut dapat diantisipasi dan mencapai tujuan yang diharapkan. Dunn pun menjelaskan bahwa:

$\begin{array}{lr}\text { “Perumusan masalah dapat membantu } \\ \text { menemukan asumsi-asumsi } & \text { yang } \\ \text { tersembunyi,mendiagnosis } & \text { penyebab- } \\ \text { penyebabnya, memetakan tujuan-tujuan yang } \\ \text { memungkinkanmemadukan } \\ \text { pandangan yang bertentangan, dan merancang } \\ \text { peluang-peluang kebijakan yang baru” (Dunn, } \\ \text { 1993: 26). }\end{array}$

Berdasarkan penjelasan di atas dapat disimpulkan bahwa langkah awal dari pembuatan kebijakan publik adalah perumusan kebijakan publik dengan menyusun setiap permasalahan publik yang terjadi seperti suatu agenda. Contohnya Rancangan Undang-Undang.

Merumuskan masalah publik yang benar dan tepat dapat didasarkan atau melihat dari karakteristik masalah publik, yaitu:

\begin{tabular}{|c|c|c|}
\hline No & $\begin{array}{l}\text { Karakteristik } \\
\text { Masalah } \\
\text { Publik }\end{array}$ & Penjelasan \\
\hline 1. & $\begin{array}{l}\text { Saling } \\
\text { bergantung } \\
\text { (interdepen- } \\
\text { dence) }\end{array}$ & $\begin{array}{l}\text { Bahwa suatu masalah kebijakan di suatu bidang seringkali mempengaruhi masalah } \\
\text { kebijakan lainnya. }\end{array}$ \\
\hline 2. & $\begin{array}{l}\text { Subjektifitas } \\
\text { (subjective) }\end{array}$ & $\begin{array}{l}\text { Kondisi eksternal yang menimbulkan suatu masalah didefinisikan,diklasifikasikan, } \\
\text { dijelaskan dan dievaluasi secara selektif. Masalah kebijakan merupakan suatu hasil } \\
\text { pemikiran yang dibuat pada suatu lingkungan tertentu, masalah tersebut merupakan } \\
\text { elemen dari suatu situasi masalah yang diabstrasikan sari situasi tersebut oleh analis. }\end{array}$ \\
\hline 3. & $\begin{array}{l}\text { Sifatnya } \\
\text { buatan } \\
\text { (artificial) }\end{array}$ & $\begin{array}{l}\text { Masalah kebijakan merupakan buah pandangan subjektif manusia, cenderung diterima } \\
\text { sebagai definisi yang sah mengenai kehidupan banyak orang. Masalah-masalah kebijakan } \\
\text { hanya mungkin ketika manusia membuat penilaian mengenai keinginannya untuk } \\
\text { mengubah beberapa situasi masalah. }\end{array}$ \\
\hline 4. & $\begin{array}{l}\text { Dinamis } \\
\text { (Dynamics) }\end{array}$ & $\begin{array}{l}\text { Masalah dan pemecahannya berada dalam siatuasi perubahan yang terus menerus. Ada } \\
\text { banyak solusi yang bisa ditawarkan untuk memecahkan masalah sebagaimana terdapat } \\
\text { banyak definisi terhadap masalah tersebut. Cara pandang orang terhadap masalah akan } \\
\text { menentukan solusi yang ditawarkan. }\end{array}$ \\
\hline
\end{tabular}

Tabel Karakteristik Masalah Publik 


\section{Tugas Pemerintah Dalam Menyelesaikan \\ Masalah - Masalah Sosial: Tinjauan Mengenai Masalah Badan Usaha Milik Desa \\ (Eka Nurcahya)}

Menurut William Dunn terdapat 4 cara untuk merumuskan kebijakan, yang di breakdown menjadi beberapa fase dalam merumuskan kebijakan :

1. Pencarian Masalah (Problem Search)

2. Pendefinisian Masalah (Problem-Definition)

3. Spesifikasi Masalah (Problem-Spesification)

4. Pengenalan Masalah (Problem-Sensing)

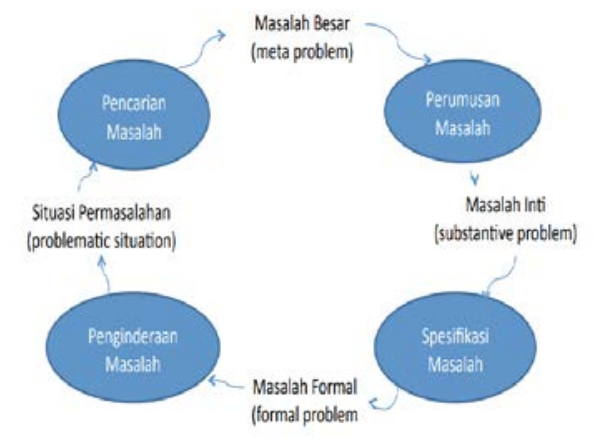

Gambar Tahap-Tahap Perumusan Masalah

Mekanisme kerja pertama. Apapun masalahnya, seorang analis perlu memahami situasi masalah (Problem Situation) yang mendasari munculnya sebuah masalah. Situasi masalah dapat ditelusuri dengan melakukan pengenalan masalah (Problem Sensing). Analis menginventarisir cara pandang yang muncul dari berbagai kelompok terhadap masalah kebijakan. Mekanisme kerja kedua. Tahap berikutnya analis menyusun meta masalah (Meta problem). Hal ini dilakukan dengan menelusuri atau mencari/ meneliti munculnya masalah (Problem Search). Tujuan dari setiap alternatif masalah harus ditetapkan.Meta masalah dilakukan karena rumitnya masalah kebijakan, yang disebabkan beragamnya pandangan aktor terhadap suatu masalah.

Mekanisme kerja ketiga. Analis melakukan konseptualisasi/definisi masalah (Problem definition) yang pada akhirnya akan menemukan Masalah Substansif (Subtantive Problem). Cara lain adalah melalui inventarisasi atau menilai/mengkritik tiap-tiap cara pandang dari pelaku kebijakan terhadap meta masalah. Hasil kritik ini digunakan untuk memilih dan menetapkan cara pandang mana yang terbaik (dimata analis) untuk kemudian digunakan sebagai pijakan dalam perumusan masalah.

Mekanisme kerja keempat. Setelah substansi masalah dapat ditemukan, analis melakukan spefisikasi masalah (Problem Specification), dengan tujuan untuk menghasilkan sebuah rumusan masalah atau masalah formal (Formal Problem). Tahap ini adalah sebagai puncak aktivitas perumusan masalah

\section{BUMDes}

BUMDes secara spesifik tidak dapat disamakan dengan badan hukum seperti perseroan terbatas, CV, atau koperasi. Oleh karenanya, BUMDesa merupakan suatu badan usaha bercirikan Desa yang dalam pelaksanaan kegiatannya di samping untuk membantu penyelenggaraan pemerintahan desa, juga untuk memenuhi kebutuhan masyarakat desa. Berbeda dengan Badan Usaha Milik Negara yang bentuknya merupakan perseroan terbatas yang modalnya terbagi dalam saham yang seluruh atau paling sedikit 51 persen sahamnya dimiliki oleh negara, serta Badan Usaha Milik Daerah yang dapat berbentuk perusahaan umum daerah dan perusahaan perseroan daerah.

Selanjutnya, Pasal 8 Permendesa 4/2015 sebagai suatu peraturan pelaksana, menyatakan bahwa BUMDesa dapat membentuk unit usaha yang meliputi perseroan terbatas atau lembaga keuangan mikro. Artinya, desa memiliki dua pilihan terkait bentuk unit usaha yang akan dibentuknya. Meskipun telah mengatur tentang pengelolaan dan pengawasan terhadap jalannya BUMDesa, akan tetapi peraturan perundang-undangan terkait belum menjelaskan secara eksplisit konsekuensi pengelolaan dan pengawasan keuangan negara dalam dana desa pada BUMDesa.

BUMDes sebagai salah satu sumber dari pendapatan asli desa diharapkan dapat mengelola aset, jasa pelayanan, dan usaha lainnya untuk sebesarbesarnya kesejahteraan masyarakat desa. Dalam mencapai tujuan tersebut, kepala desa sebagai pemerintah desa diberi wewenang dalam fungsi ekonomi antara lain untuk mengembangkan sumber pendapatan desa, dan mengusulkan dan menerima pelimpahan sebagian kekayaan negara guna meningkatkan kesejahteraan masyarakat desa.

BUMDes adalah badan usaha yang seluruh atau sebagian besar modalnya dimiliki oleh Desa melalui penyertaan secara langsung yang berasal dari kekayaan Desa yang dipisahkan. Selain itu, BUMDes memperoleh pula penyertaan modal dari masyarakat Desa berupa tabungan atau simpanan masyarakat. Penyertaan modal desa kepada BUMDes salah satunya terdiri dari kerjasama usaha desa dengan pihak swasta, lembaga sosial ekonomi kemasyarakat, dan/atau lembaga donor yang dipastikan sebagai kekayaan kolektif Desa dan disalurkan melalui mekanisme APB Desa. Sistem demokrasi ekonomi yang merupakan penjabaran dari Pasal 33 UUD 1945 secara jelas menyebutkan bahwa pengelolaan kegiatan ekonomi harus dilaksanakan secara kekeluargaan. 


\section{Metode}

Metode yang digunakan untuk penulisan ini adalah Studipustaka. StudiPustaka dilakukan karena banyaknya informasi dan data mengenai BUMDes. Hal ini dapat ditelusuri melalui berbagai informasi dalam buku, jurnal ilmiah, koran, majalah, serta sumber informasi dari laman situs/website melalui internet. Studi pustaka menjadi penting dalam menganalisa tugas pemerintah dalam menyelesaikan masalah-masalah sosial; tinjauan mengenai masalah BUMDes.

\section{Analisis Mengenai Tugas Pemerintah Dalam Menyelesaikan Masalah Sosial, Tinjauan Mengenai BUMDes}

Membangun Indonesia dari pinggiran dengan memperkuat daerah dan desa merupakan agenda prioritas Indonesia. Tujuannya untuk memajukan perekonomian masyarakat desa dan mengatasi kesenjangan pembangunan nasional. Hal ini dapat diwujudkan melalui pembentukan Badan Usaha Milik Desa. Di era reformasi, muncul tuntutan bahwa perumusan kebijakan publik harus didasarkan pada tata pemerintahan yang baik atau governance. Masalah yang muncul adalah bagaimana peran aktor governance dalam perumusan peraturan desa pembentukan BUMDes.

Sesuai dengan isi dari Nawa Cita yang ke tiga yaitu "Membangun Indonesia dari pinggiran dengan memperkuat daerahdaerah dan desa dalam kerangka negara kesatuan". Tujuan pengaturan desa yaitu memajukan perekonomian masyarakat desa dan mengatasi kesenjangan pembangunan nasional serta memperkuat masyarakat desa sebagai subjek pembangunan, salah satunya dapat diwujudkan melalui pembentukan Badan Usaha Milik Desa sebagaimana diatur pada Bab X Undang-undang Nomor 6 Tahun 2014.

Pembentukan dan pengelolaan Badan Usaha Milik Desa juga diatur khusus dalam Permendes PDTT Nomor 4 tahun 2015. BUMDes merupakan usaha desa yang bercirikan kepemilikan kolektif, bukan hanya dimiliki oleh individu, melainkan menjadi milik pemerintah desa dan masyarakat. Memasuki era reformasi, muncul tuntutan bahwa perumusan suatu kebijakan publik harus didasarkan kepada tata pemerintahan yang baik (governance) dalam dua dekade terakhir, istilah "governance" menjadi perbendaharaan yang sering digunakan dalam diskusi administrasi publik dan demokrasi (Pramusinto, 2012: 2). Konsep governance menawarkan interaksi antara tiga aktor utama dalam perumusan suatu kebijakan, aktor tersebut adalah negara (state), masyarakat (society) dan sektor swasta (private).

Governance adalah basis penyelenggaraan otonomi lokal, pemerintahan lokal yang kuat dan otonom tidak akan bermanfaat dan berguna bagi masyarakat apabila tidak ditopang oleh transparansi, akuntabilitas, responsivitas dan partisipasi masyarakat. Secara teoritis, prinsip penting yang menjadi pilar dalam struktur itu ditandai oleh adanya; (a) partisipasi; (b) transparansi; (c) kontrol dan; (d) akuntabilitas. Kerangka governance yang bersifat makro tersebut dapat diterapkan pada level desa, sehingga dalam perumusan kebijakan publik pada level desa dapat dipandang dalam perspektif governance. Ada dua pihak yang diharapkan berperan aktif mengembangkan BUMDes, yakni pemerintah daerah dan swasta. Pemda diharapkan membantu dalam bentuk regulasi, program maupun bantuan teknis dan permodalan. Pihak swasta diharapkan melakukan kemitraan pendampingan maupun permodalan baik yang terkait langsung dengan kegiatan pemberdayaan usaha ekonomi masyarakat maupun program perusahaan.

Pemerintah desa sebagai satuan pemerintahan terendah memegang peran garda terdepan dalam penyelenggaraan pemerintahan dan pembangunan. Dalam undang-undang mengatur bahwa pemerintah Desa memiliki tugas menyelenggarakan pemerintahan yang memiliki hak, wewenang dan kewajiban untuk mengatur dan mengurus sendiri urusan pemerintahan dan kepentingan masyarakat berdasarkan hak asal-usul dan adat istiadat setempat. Masyarakat desa memiliki kesempatan yang sama untuk tumbuh dan berkembang mengikuti perubahan-perubahan baik dibidang ekonomi, politik, dan sosial budaya. Namun perubahanperubahan itu diharapkan tetap sesuai dan tidak meninggalkan tata nilai sosial budaya yang ada di Desa, seperti kekerabatan, gotong royong, dan kearifan.

Dalam melaksanakan urusan pemerintahan yang menjadi kewenangannya dan untuk memberikan pelayanan serta pemberdayaan masyarakat, Desa memiliki sumber-sumber pendapatan yang terdiri dari pendapatan Asli Desa (PADes), bagi hasil pajak dan retribusi daerah kabupaten, bagian dari dana perimbangan keuangan pusat dan daerah diterima oleh kabupaten, bantuan dari pemerintah dan pemerintah daerah serta hibah dan sumbangan dari pihak ketiga.

Salah satu sumber PADes yang dapat diusahakan oleh pemerintah Desa adalah dengan mendirikan Badan Usaha Milik Desa (BUM Desa), yaitu suatu lembaga/badan perekonomian Desa yang dibentuk dan dimiliki oleh pemerintah Desa dan masyarakat, dikelola secara ekonomis mandiri dan profesional. Walaupun seyogyanya Desa memiliki Alokasi Dana Desa (ADD) yang berasal dari anggaran pendapatan dan belanja daerah (APBD) kabupaten, namun diperlukan juga suatu badan yang mengurus kekayaan asli Desa demi terjadinya keseimbangan dana pembangunan. Untuk itu perlu suatu lembaga yang dapat mengelola potensi Desa dengan maksimal, maka didirikanlah Badan Usaha Milik Desa (BUM Desa) yang seluruh modalnya berasal dari kekayaan Desa seperti 


\section{Tugas Pemerintah Dalam Menyelesaikan \\ Masalah - Masalah Sosial: Tinjauan Mengenai Masalah Badan Usaha Milik Desa \\ (Eka Nurcahya)}

industri berbasis masyarakat, pertanian, pertambangan, perkebunan, perdagangan, pariwisata, dan lainlain. Pemerintahan Desa dilaksanakan oleh Kepala Desa sebagai Badan Eksekutif dan Badan Permusyawaratan Desa (BPD) sebagai Badan Legislatif. Pemerintahan Desa inilah yang selanjutnya mengayomi masyarakat serta mengurus kepentingan Desa dalam bidang pemerintahan dan pembangunan. Kementrian Desa, PDT, dan Transmigrasi berkomitmen mewujudkan harapan UU Desa dan Nawa Cita. Dalam konteks tersebut BUM Desa diposisikan sebagai salah satu kebijakan untuk mewujudkan Nawa Cita.

Ditinjau dari karakteristik masalah publik menurut Dunn, BUMDes ini termasuk dalam masalah publik. Analisis dari karakteristik saling bergantung (interdependence) yaitu masalah kebijaksanaan dalam suatu bidang seringkali mempengaruhi masalah kebijaksanaan lainnya. Pada kenyataannya masalah kebijaksanaan bukan merupakan kesatuan yang berdiri sendiri, mereka merupakan bagian dari seluruh sistim masalah yang disebut sebagai messes, yaitu sistim kondisi eksternal yang menghasilkan ketidakpuasan dari setiap kelompok masyarakat. Dengan adanya BUMDes dapat dikatakan menjadi masalah publik sebelumnya karena dalam hal ini masalah saling ketergantungan, di satu sisi karena faktor ekonomi yang kurang mencukupi, tingkat kebutuhan yang semakin meningkat dan pendapatan yang rendah serta tidak diiringi oleh pembinaan \& motivasi tinggi untuk berusaha.

Masalah kebijaksanaan (policy problem) "adalah produk aktifitas berfikir terhadap lingkungan; problem merupakan elemen dari situasi problematis yang diabstraksi dari suatu situasi tertentu oleh analis. Karena itu, yang kita alami adalah situasi problematis (problematic situation), bukan problem itu sendiri, seperti atom atau sel, merupakan CONSTRUCTS yang konseptual”. Dalam analisa kebijaksanaan penting sekali untuk tidak mencampuradukkan situasi problematis dengan problem atau masalah kebijaksanaan, karena problem kebijaksanaan merupakan buah pikiran yang timbul melalui pemindahan pengalaman kedalam pikiran manusia. Maka dari itu, dengan didirikannya BUMDes adalah akibat penilaian subjektivitas pemerintah untuk turut andil mengatasi masalah sosial terkhusus faktor ekonomi yang dirasakan oleh masyarakat.

Analis mengakaji situasi masalah (Problem Situation) yang mendasari munculnya sebuah masalah. Situasi masalah dapat ditelusuri dengan melakukan pengenalan masalah (Problem Sensing). Analis menginventarisir cara pandang yang muncul dari berbagai kelompok terhadap masalah kebijakan. Dari pemahaman BUMDes diatas sudah terlihat jelas bahwa pemerintah sudah mengkaji dan menyatakan bahwa BUMDEs adalah upaya untuk membangun Indonesia dari pinggiran dengan memperkuat daerahdaerah dan desa dalam kerangka negara kesatuan. Tujuan pengaturan desa yaitu memajukan perekonomian masyarakat desa dan mengatasi kesenjangan pembangunan nasional serta memperkuat masyarakat desa sebagai subjek pembangunan, salah satunya dapat diwujudkan melalui pembentukan Badan Usaha Milik Desa sebagaimana diatur pada Bab X Undang-undang Nomor 6 Tahun 2014.

Selanjutnya analis mengkaji dalam tahap pemerintah menyusun meta masalah (Meta problem). Hal ini dilakukan dengan menelusuri atau mencari/ meneliti munculnya masalah (Problem Search). Indikator tertinggal adalah desa yang memiliki tingkat kemiskinan tinggi, memiliki mayoritas penduduk yang miskin, belum mandiri secara ekonomi pedesaan, lingkungan hidup yang tidak terkelola dengan baik dan masih kurangnya akses terhadap pelayanan dasar.cKondisi ini sangat kontradiktif dengan tujuan otonomi daerah. Hal tersebut menjadi meta masalah dalam tugas pemerintah sehingga mendirikan BUMDes. Analis melakukan konseptualisasi/definisi masalah (Problem definition) yang pada akhirnya akan menemukan Masalah Substansif (Subtantive Problem). Setelah substansi masalah dapat ditemukan, analis melakukan spefisikasi masalah (Problem Specification), dengan tujuan untuk menghasilkan sebuah rumusan masalah atau masalah formal (Formal Problem). Tahap ini adalah sebagai puncak aktivitas perumusan masalah.

\section{Kesimpulan}

Masalah kemiskinan merupakan salah satu masalah publik, karena jika dilihat dari karakteristik masalah publik. Membangun Indonesia dari pinggiran dengan memperkuat daerah dan desa merupakan agenda prioritas Indonesia. Tujuannya untuk memajukan perekonomian masyarakat desa dan mengatasi kesenjangan pembangunan nasional. Hal ini dapat diwujudkan melalui pembentukan Badan Usaha Milik Desa. Di era reformasi, muncul tuntutan bahwa perumusan kebijakan publik harus didasarkan pada tata pemerintahan yang baik atau governance. Masalah yang muncul adalah bagaimana peran aktor governance dalam perumusan peraturan desa pembentukan BUMDes. Sehingga pemerintah mengeluarkan kebijakan sebagaimana diatur pada Bab X Undangundang Nomor 6 Tahun 2014 dan Permendes PDTT Nomor 4 tahun 2015.

\section{Saran}

Kemiskinan merupakan salah satu masalah publik yang memiliki permasalahan yang kompleks, maka Pemerintah dalam mengeluarkan Kebijakan terkait BUMDes perlu mempertimbangkan dari berbagai aspek kehidupan, dilakukan dengan beberapa pendekatan, dan diharapkan dapat mengakomodasi semua kepentingan agar Kebijakan yang dihasilkan tidak merugikan salah satu pihak. 
BUMDes sebagai salah satu sumber dari pendapatan asli desa diharapkan dapat mengelola aset, jasa pelayanan, dan usaha lainnya untuk sebesarbesarnya kesejahteraan masyarakat desa. Dalam mencapai tujuan tersebut, kepala desa sebagai pemerintah desa diberi wewenang dalam fungsi ekonomi antara lain untuk mengembangkan sumber pendapatan desa, dan mengusulkan dan menerima pelimpahan sebagian kekayaan negara guna meningkatkan kesejahteraan masyarakat desa.

\section{DAFTAR PUSTAKA}

Dunn, William N. 1992. Analisa Kebijaksanaan Publik. Yogyakarta: Prasetya Offset.

Dunn, William N. 1998. Pengantar Analisis Kebijakan Publik. Yogyakarta: Gadjah Mada University Press.
Islamy, Irfan. 2004. Prinsip-Prinsip Perumusan Kebijaksanaan Negara. Jakarta: Bumi Aksara.

Suryaningrat, Bayu. 1989. Perumusan Kebijaksanaan dan Koordinasi Pembangunan di Indonesia. Jakarta: Bina Aksara.

Pramusinto, A \& M. Syahbudin. 2012. Dinamika Good Governance di Tingkat Desa. Jurnal Administrasi Negara (11): 1- 13.

Undang-Undang Nomor 32 Tahun 2004 tentang Pemerintah Daerah pada Pasal 213 ayat 1-3

Undang-undang Nomor 6 Tahun 2014

Permendes PDTT Nomor 4 tahun 2015 